\title{
Isolation of two iron-reducing facultative anaerobic electricigens and probing the application performance in eutrophication water
}

\author{
Xia Zhang ${ }^{1,2}$, Hongpei Zhang ${ }^{1,2}$, Chuan Wang ${ }^{2}$, Qianru Chen ${ }^{1,2}$, Yuqing Zhao ${ }^{1,2}$, Qiaohong Zhou ${ }^{2 *}$ and \\ Zhenbin $\mathrm{Wu}^{2^{*}}$
}

\begin{abstract}
Purpose: Sediment microbial fuel cell (SMFC) is a promising bioremediation technology in which microbes play an important role. Electricigens as the bio-catalysts have effect on pollution control and electricity generation. It is of great significance to screen the microorganisms with the ability of generating electricity.

Methods: The SMFC anode biofilm was used as microbiological source to study the feasibility of electricigens with iron-reducing property for eutrophication water treatment. Preliminarily, we isolated 20 facultative anaerobic pure bacteria and evaluated their cyclic voltammogram (CV) through the three-electrode system and electrochemical workstation. The power generation performance of strains was verified by air-cathode microbial fuel cells (AC-MFCs) under different single carbon sources.

Result: According to its morphological, physiological, and biochemical characteristics, along with phylogenetic analysis, the two strains (SMFC-7 and SMFC-17) with electrical characteristics were identified as Bacillus cereus. Compared with SMFC-7, SMFC-17 exhibited efficient $\mathrm{NH}_{4}{ }^{+}-\mathrm{N}$ and $\mathrm{NO}_{3}{ }^{-}-\mathrm{N}$ removal and $\mathrm{PO}_{4}{ }^{3-}{ }^{-} \mathrm{P}$ accumulation from eutrophic solution with a removal rate of $79.91 \pm 6.34 \%$ and $81.26 \pm 1.11 \%$ and accumulation rate of $57.68 \pm 4.36 \%$, respectively.
\end{abstract}

Conclusion: The isolated bacteria SMFC-17 showed a good performance in eutrophic solution, and it might be a useful biocatalyst to enable the industrialized application of SMFC in eutrophic water treatment.

Keywords: Sediment microbial fuel cell (SMFC), Electricigens, Cyclic voltammograms (CVs), Biocatalyst, Eutrophic water, Bacillus

\section{Introduction}

Eutrophication of water body has an important impact on the living environment of human beings (Morgane et al., 2019). The input of nutrients, such as the diffusion loss of nitrogen and phosphorus, is the main drivers of eutrophication (Beusen, Bouwman, Van Beek, Mogollón,

\footnotetext{
* Correspondence: qhzhou@ihb.ac.cn; wuzb@ihb.ac.cn

${ }^{2}$ State Key Laboratory of Freshwater Ecology and Biotechnology, Institute of Hydrobiology, Chinese Academy of Sciences, Wuhan 430072, People's

Republic of China

Full list of author information is available at the end of the article
}

\& Middelburg, 2016). Exogenous pollution has been kept down to some extent with the strengthening of water pollution management and treatment, whereas the treatment of endogenous pollution has become the important issue of eutrophication treatment (Wang et al., 2017; Wang et al., 2019). As an important component of the water environment, the sediment presents not only a natural reservoir but also a potential source of long-term releasing contaminants to the water. Thus, the remediation of sediment is the key link to improve the quality

(c) The Author(s). 2020 Open Access This article is licensed under a Creative Commons Attribution 4.0 International License, which permits use, sharing, adaptation, distribution and reproduction in any medium or format, as long as you give

appropriate credit to the original author(s) and the source, provide a link to the Creative Commons licence, and indicate if changes were made. The images or other third party material in this article are included in the article's Creative Commons licence, unless indicated otherwise in a credit line to the material. If material is not included in the article's Creative Commons licence and your intended use is not permitted by statutory regulation or exceeds the permitted use, you will need to obtain permission directly from the copyright holder. To view a copy of this licence, visit http://creativecommons.org/licenses/by/4.0/. 
of the water environment (Karra et al., 2014; Li \& Yu, 2015).

Sediment microbial fuel cells (SMFCs) have been used to utilize bioelectricity from water-based ecosystems, where electro-chemically active microbes metabolize biodegradable organic matter $(\mathrm{OM})$ in sediments and produce electrons (Xu et al., 2017). Due to the capacities of power generation and pollution control, SMFCs have lots of potential for future application. For instance, SMFCs have been used for bioremediation of the overlying water in the sediment-water systems (Sajana, Ghangrekar, \& Mitra, 2013; Sajana, Ghangrekar, \& Mitra, 2014), sediment remediation by biodegradation of organic pollutants (Hong, Kim, \& Chung, 2010), and phosphorus immobilization (Martins et al., 2014). As the biocatalysts, electricigens play a role in pollution control and electricity generation. Electricigens are a kind of microorganisms that can directly or indirectly oxidize and decompose pollutants to obtain electrons and transfer them to anode to generate current (Lovley, 2006). They may be denitrifying bacteria (Virdis, Rabaey, Rozendal, Yuan, \& Keller, 2010; Xiao, Zheng, Wu, Yang, \& Zhao, 2015), phosphorous accumulating bacteria (Tao et al., 2014), or bacteria that degrade other difficult pollutants (Pham et al., 2003; Xu et al., 2005; Biffinger et al., 2011). To date, many studies have focused on characterizing the microbiological community structure of the anode biofilm to analyze the microbial species (Ewing, Ha, \& Beyenal, 2017; Kabutey et al., 2019; Xu et al., 2017). Referring to the reported literatures on electricigens (Kumar, Singh, \& Zularisam, 2016), we can speculate which bacteria in the biofilm play a role in electricity production. However, the specific electricity-producing properties under specific conditions still need to be further verified, because the electricity-producing properties of each strain are different under different conditions. Moreover, the types of electricigens obtained by analysis were difficult to specific species. Therefore, it is of great significance to screen the microorganisms with the ability of generating electricity. Several studies have developed methods and devices that can be used for isolating electricigens, such as U-tube MFCs (Zuo, Xing, Regan, \& Logan, 2008), $\mathrm{WO}_{3}$ nanocluster probe (Yang et al., 2016), and electrodeplate-culture (EPC) method (Ueoka, Kouzuma, \& Watanabe, 2018). At present, there is no unified screening method for electricigens, and most of the electricigens are obtained through anaerobic separation technology. Wu et al. (2014) used traditional aerobic separation technology to obtain 3 electricigens from micro-oxygen anode. The screened electricigens had similar direct extracellular electron transfer mechanism, indicating that microoxygen anode could be oriented to screen for electricigens with similar electrochemical properties. Successive experiments have proved that many iron-reducing bacteria have the ability to produce electricity (Liu et al., 2016; Liu \& Wang, 2016; Park et al., 2001) and most of the electricigens are facultative anaerobic bacteria (Seo \& Roh, 2018). Screening iron-reducing bacteria capable of rapidly transforming organic matter into electricityproducing bacteria has become an urgent need to promote the development of MFC. It is a trend to isolate and screen iron-reducing bacteria suitable for MFC directly from well-functioning MFC anodes, so that the physiological conditions (such as $\mathrm{pH}$, temperature, and electron donors) of the strains are close to their original habitats. Thus, we speculate that screening the microorganism with iron-reducing property in the anode biofilm by micro-oxygen condition is beneficial to obtain the electrogenic microorganism with a similar property quickly.

In pursuance of our quest for the desired microbes, this research work presents the isolation and identification of two bacterial strains from a lab-scale SMFC used for the treatment of eutrophic water. The objectives of the study include the following: (1) verifying the feasibility of the screening method through screening ironreducing bacteria under micro-oxygen environment to obtain electricigens and (2) exploring the nitrogen removal performance and phosphorus accumulation efficiency of the isolated strains under experimental conditions to demonstrate the potential applications of the microbe in the treatment of eutrophic water bodies.

\section{Materials and methods}

\section{Growth medium, inoculation, and cultivation}

The sample was obtained from the anodic biofilm of a SMFC (Xu et al., 2017). The biofilm attached to the anode graphite felt was scraped off in aseptic condition and inoculated into an anaerobic bottle $(100 \mathrm{~mL})$ containing $50 \mathrm{~mL}$ of LB medium (peptone, $10 \mathrm{~g} / \mathrm{L}$; yeast extract, $5 \mathrm{~g} / \mathrm{L} ; \mathrm{NaCl} 10 \mathrm{~g} / \mathrm{L}, \mathrm{pH}=7.0 \pm 0.2$, sterilization at $121{ }^{\circ} \mathrm{C}$ for $\left.20 \mathrm{~min}\right)$. The anaerobic bottle was incubated at $30{ }^{\circ} \mathrm{C}$ for 1 day, and then $1.00 \mathrm{~mL}$ of culture broth was added into the iron-reducing medium (IRM). The composition of the IRM was $2.5 \mathrm{~g} / \mathrm{L} \mathrm{NaHCO}_{3}, 0.6 \mathrm{~g} / \mathrm{L}$ $\mathrm{KH}_{2} \mathrm{PO}_{4}, 1.5 \mathrm{~g} / \mathrm{L} \mathrm{NH} \mathrm{Nl}_{4} \mathrm{Cl} 0.5 \mathrm{~g} / \mathrm{L}$ yeast extract, $20 \mathrm{mM}$ $\mathrm{CH}_{3} \mathrm{COONa}$, ferric citrate $20 \mathrm{mM}(\mathrm{pH} 7.0 \pm 0.2)$, and sterilization at $121{ }^{\circ} \mathrm{C}$ for $20 \mathrm{~min}$. The liquid medium was incubated at $30^{\circ} \mathrm{C}$ for 4 days under a micro-oxygen condition (DO $<1 \mathrm{mg} / \mathrm{L}$ ) that was purged with $99 \% \mathrm{~N}_{2}$ gas. The culture broth was serially diluted and then spread on the solid IRM, which contained $2.0 \%$ agar. The plates were cultivated at 30 for 4 days in an anaerobic incubator. According to the characteristics of colony morphology, color, and transparency formed on the plate, all the colony types that formed under solid IRM were picked and re-inoculated on the solid plates of 
IRM and LB medium and then incubated at $30{ }^{\circ} \mathrm{C}$ for 3 days in an anaerobic incubator. This process was repeated at least 5 times to obtain a batch of purified strains.

\section{Electrochemical analysis}

Three-electrode system was prepared for testing cyclic voltammograms (CVs) of strains, which consist of a working electrode, counter electrode, and saturated calomel reference electrode $\left(\mathrm{SCE}, \mathrm{Hg} / \mathrm{Hg}_{2} \mathrm{Cl}_{2}\right.$ saturated $\mathrm{KCl}$, $+0.244 \mathrm{~V}$ vs. hydrogen standard electrode (SHE)). The purified strains were inoculated separately into IRM medium and cultured under anaerobic conditions for 3 days. Sixty milliliters of bacterial solution was taken under anaerobic conditions for CVs scanning. The CVs of the cell suspensions were obtained using a CS 2350 electrochemical workstation. The scan rate of $100 \mathrm{mV} / \mathrm{s}$ was employed over the range from -0.8 to $0.8 \mathrm{~V}$.

To test the electricity production of strains that have obvious redox peaks, a series of membrane-free single chamber air-cathode microbial fuel cells (AC-MFCs, 28 $\mathrm{mL}$ working volume) were constructed to evaluate the current production of the purified strains under different single carbon sources. The reaction chamber is a cylinder with a column length of $4 \mathrm{~cm}$ and an inner diameter of $4 \mathrm{~cm}$. Both electrodes were carbon cloth (the area is $3.14 \mathrm{~cm}^{2}$ ). The air cathode is a platinum-loaded carbon cloth with a platinum loading of $0.5 \mathrm{mg} \mathrm{cm}{ }^{-2}$ and four layers of polytetrafluoroethylene (PTFE) coated on the air to prevent leakage and regulate oxygen permeation. The anode was treated with acetone for $24 \mathrm{~h}$ to remove some non-compatible impurities from the surface of the carbon cloth.

For the AC-MFCs inoculation, the pure bacteria under logarithmic stage were centrifuged and dissolved again in $50 \mathrm{mmol} \mathrm{L}^{-1} \mathrm{PBS}$ buffer (sterilization at $121{ }^{\circ} \mathrm{C}$ for 20 $\mathrm{min}$ ), and this process was repeated 3 times. The bacterial suspension was mixed with a nutrient solution containing $20 \mathrm{mmol} \mathrm{L}^{-1}$ single electron donor (sodium citrate, glucose, sodium acetate, sodium lactate, sodium oxalate, glycerol) in a ratio of 1:5 and then inoculated into AC-MFCs. All operations are carried out under aseptic conditions. External resistance is $1000 \Omega$, operating at $30 \pm 1{ }^{\circ} \mathrm{C}$ constant temperature. The output voltage (V) of the AC-MFCs is measured using R6016/U (Shanghai Jisheng Electric) every $10 \mathrm{~min}$.

\section{S rDNA gene sequencing and analysis}

The single purified strains were used as template for PCR-mediated amplification of $16 \mathrm{~S}$ rDNA with the universal primers $27 \mathrm{f}$ and 1492r. The PCR amplification was performed in a $30-\mu \mathrm{L}$ reaction volume containing 1 $\mu \mathrm{L}$ of DNA, $1 \mu \mathrm{L}$ of each primer (10 Mp), $15 \mu \mathrm{L}$ of $2 \times$ Power Taq PCR MasterMix, and $12 \mu \mathrm{L} \mathrm{ddH}_{2} \mathrm{O}$. PCR amplification was carried out with an initial predenaturation of DNA at $95^{\circ} \mathrm{C}$ for $3 \mathrm{~min}$, denaturation at $95{ }^{\circ} \mathrm{C}$ for $30 \mathrm{~s}$, annealing at $58{ }^{\circ} \mathrm{C}$ for $30 \mathrm{~s}$, extension at $72{ }^{\circ} \mathrm{C}$ for $50 \mathrm{~s}, 30$ cycles, and finally at $72{ }^{\circ} \mathrm{C}$ for $5 \mathrm{~min}$. Agarose gel electrophoresis analysis was amplified by product PCR for sequence determination. The $16 \mathrm{~S}$ rDNA gene sequences were queried against the GenBank using the BioCloud (www.ezbiocloud.net/identify). Phylogenetic relationships were analyzed by the evolutionary distance matrix calculated using the neighborjoining method with Kimura's two-parameter method. A neighbor-joining tree was constructed with the program MEGA7.

Biochemical tests of the isolated strains were performed with Solarbio Gram stain kit and Bacillus cereus biochemical identification box.

\section{Performance analysis of electricigens}

Effects of temperature and $\mathbf{p H}$ The pure bacteria under logarithmic stage were streaked on LB solid medium and placed in a constant temperature incubator at $4,10,20,30,35,37$, and $45^{\circ} \mathrm{C}$. To determine the optimum growth $\mathrm{pH}$ of the strain, the strain was inoculated in 50\% LB liquid medium at a $1 \%$ inoculum, and the $\mathrm{pH}$ was adjusted to $4,5,6,7,8$, and 9 with $1 \mathrm{M} \mathrm{HCl}$ and $1 \mathrm{M} \mathrm{NaOH}$, respectively.

Iron reduction performance The pure bacteria under logarithmic stage were centrifuged 3 times and reset in sterile water with an $\mathrm{OD}_{600}$ of 0.5 . The bacterial liquid was inoculated into $50 \mathrm{~mL}$ iron-reducing medium (IRM) with different concentrations of ferric citrate $(5 \mathrm{mM}$ and $20 \mathrm{mM}$ ) at a $1 \%$ inoculum, respectively. The anaerobic bottle is filled with a sterile $\mathrm{N}_{2}$ (5 min) to maintain a micro-oxygen environment and then placed at $30{ }^{\circ} \mathrm{C}$. The sample was centrifuged at $3500 \mathrm{r} / \mathrm{min}$ for $5 \mathrm{~min}$ every $24 \mathrm{~h}$, and the contents of Fe(II) and Fe(III) in the supernatant were determined for 7 days. The medium without the addition of bacteria was blank control. All experiments were conducted in triplicate.

Nitrogen removal efficiency and phosphorus accumulation rate To compare the performance difference of pure bacteria and the mixed bacteria, they were cultured to the logarithmic phase, centrifuged three times, and dissolved again in sterile water with an $\mathrm{OD}_{600}$ of 0.5 , respectively. The bacterial liquid was inoculated into the formulated eutrophic liquid medium $\left(\mathrm{MgSO}_{4} \cdot 7 \mathrm{H}_{2} \mathrm{O}, 91.26 \mathrm{mg} / \mathrm{L} ; \mathrm{CH}_{3} \mathrm{COONa} \cdot 3 \mathrm{H}_{2} \mathrm{O}, 3.32 \mathrm{~g} /\right.$ L; $\mathrm{NH}_{4} \mathrm{Cl}, 305.52 \mathrm{mg} / \mathrm{L} ; \mathrm{KNO}_{3}, 300 \mathrm{mg} / \mathrm{L} ; \mathrm{K}_{2} \mathrm{HPO}_{4}, 25$ $\mathrm{mg} / \mathrm{L}$; PIPES buffer solution, $8.5 \mathrm{~g} / \mathrm{L} ; \mathrm{CaCl}_{2} \cdot 2 \mathrm{H}_{2} \mathrm{O}, 25.68$ $\mathrm{mg} / \mathrm{L} ; \mathrm{NaCl}, 20 \mathrm{mg} / \mathrm{L}$; trace element solution $2 \mathrm{~mL} ; \mathrm{pH}$ $7.0 \pm 0.2$, sterilization at $121{ }^{\circ} \mathrm{C}$ for $20 \mathrm{~min}$ ) at a $1 \%$ 
inoculation amount and incubated at $30{ }^{\circ} \mathrm{C}$ for 7 days. The sample was centrifuged at $8000 \mathrm{r} / \mathrm{min}$ for $5 \mathrm{~min}$ every $24 \mathrm{~h}$, and the contents of $\mathrm{NO}_{3}{ }^{-} \mathrm{N}, \mathrm{NO}_{2}{ }^{-} \mathrm{N}$, $\mathrm{NH}_{4}{ }^{+}-\mathrm{N}$, and $\mathrm{PO}_{4}{ }^{3-}$ in the supernatant were determined for 7 days. The medium without the addition of bacteria was blank. All experiments were conducted in triplicate.

The trace element solution was $\mathrm{Na}_{2}$ EDTA, $63.7 \mathrm{mg} / \mathrm{L}$; $\mathrm{MnCl}_{2} \cdot 4 \mathrm{H}_{2} \mathrm{O}, 5.06 \mathrm{mg} / \mathrm{L} ; \mathrm{ZnSO}_{4}, 2.2 \mathrm{mg} / \mathrm{L} ; \mathrm{FeSO}_{4} \cdot 7 \mathrm{H}_{2} \mathrm{O}$, $5.0 \mathrm{mg} / \mathrm{L} ; \mathrm{CaCl}_{2}, 5.5 \mathrm{mg} / \mathrm{L} ; \mathrm{CuSO}_{4} \cdot 5 \mathrm{H}_{2} \mathrm{O}, 1.57 \mathrm{mg} / \mathrm{L}$; $\mathrm{Na}_{2} \mathrm{MoO}_{4} \cdot 4 \mathrm{H}_{2} \mathrm{O}, 1.1 \mathrm{mg} / \mathrm{L} ; \mathrm{CoCl}_{2} \cdot 6 \mathrm{H}_{2} \mathrm{O}, 1.61 \mathrm{mg} / \mathrm{L}$; and pH $7.0 \pm 0.2$.

\section{Analytical methods}

Cell density in the form of OD was measured against the blank using a spectrophotometer at an absorbance of $600 \mathrm{~nm}$. The reduction of $\mathrm{Fe}(\mathrm{III})$, concentration of nitrate-nitrogen $\left(\mathrm{NO}_{3}{ }^{-} \mathrm{-N}\right)$, nitrite-nitrogen $\left(\mathrm{NO}_{2}{ }^{-} \mathrm{-N}\right)$, ammonium-nitrogen $\left(\mathrm{NH}_{4}{ }^{+}-\mathrm{N}\right)$, and phosphate $\left(\mathrm{PO}_{4}{ }^{3}\right.$ - $\mathrm{P})$ were measured by $\mathrm{O}$-phenanthroline spectrophotometry, sulfamic acid method, sulfanilic acid method, Nessler's reagent method, and persulfate digestion method, respectively (State EPA of China, 2002).

In this study, the amounts of biological assimilation, organic nitrogen, gaseous nitrogen, and absorbance were not measured. Accordingly, the nitrogen removal efficiency was calculated only based on measured values of nitrate, nitrite, and ammonium in aqueous solutions.

The calculation formula is as follows (Islam, Ethiraj, Cheng, Yousuf, \& Khan, 2017):

$$
R_{N}(\%)=\frac{\left[\mathrm{NO}_{3}^{-}\right]_{i}+\left[\mathrm{NO}_{2}^{-}\right]_{i}+\left[\mathrm{NH}_{4}^{+}\right]_{i}-\left[\mathrm{NO}_{3}^{-}\right]_{f}-\left[\mathrm{NO}_{2}^{-}\right]_{f}-\left[\mathrm{NH}_{4}^{+}\right]_{f}}{\left[\mathrm{NO}_{3}^{-}\right]_{i}+\left[\mathrm{NO}_{2}^{-}\right]_{i}+\left[\mathrm{NH}_{4}^{+}\right]_{i}} \times 100
$$

\section{Statistical analysis}

The experimental data, which were statistically calculated and drawn by office 2010 and origin 2019, were analyzed with analysis of variance (ANOVA) and $t$ test. All data were presented as the mean value and standard deviation (SD). The SPSS 18.0 was used to evaluate the significant differences among treatments by a one-way ANOVA test at the 0.05 probability level.

\section{Results and discussion}

\section{Strain selection}

According to the difference of colonies on LB and ferric citrate solid medium, a total of 20 strains were obtained from the anode biofilm, which were numbered SMFC-1 to SMFC-20. The purified 20 strains and the blank culture solution were tested for electrochemical activity. The peak value of pure bacterial suspension measured by cyclic voltammetry can represent the electrochemical activity of the strain (Wu et al., 2014). It was found that the system without adding microorganisms was no redox peak in the cyclic voltammetry curve, indicating that the system itself had substantially no electrochemical activity. The cyclic voltammetry curves of the strains SMFC1, SMFC-7, SMFC-15, SMFC-17, and SMFC-20 (Fig. 1) show certain oxidation peaks or reduction peaks, indicating the selected microorganisms have different degrees of electrochemical activity. We found that the strains SMFC7 and SMFC17 had significant redox peaks, which indicated that they had strong electrogenetic properties (Kim et al., 2002).

\section{Voltage output}

Strains SMFC-7 and SMFC-17 were inoculated into ACMFC, respectively. The results (Fig. 2) showed that under the condition of a single carbon source, both strains SMFC-7 and SMFC-17 could produce electricity using sodium citrate and sodium lactate and could not use glucose, sodium acetate, sodium oxalate, or glycerol as a single carbon source to produce electricity. When strain SMFC-7 was used to produce electricity by sodium lactate $(\mathrm{SL})$, the voltage reached the maximum value of $63 \mathrm{mV}$ in the first cycle after $24 \mathrm{~h}$. When the electricity was produced by sodium citrate (SC), the voltage reached the maximum value of $18 \mathrm{mV}$ in the first cycle after about $120 \mathrm{~h}$. When strain SMFC-17 was used to produce electricity by sodium lactate, the voltage reached the maximum value of $65 \mathrm{mV}$ in the first cycle after $75 \mathrm{~h}$. When the electricity was produced by sodium citrate, the voltage reached the maximum value of 15 $\mathrm{mV}$ in the first cycle after about $80 \mathrm{~h}$ of starting. It can be seen that strains SMFC-7 and SMFC-17 have certain similarities in electrical performance. Compared with the control experiment (the highest voltage value is $2 \mathrm{mV}$ when glucose, sodium acetate, sodium oxalate, and glycerol are the single carbon sources), we demonstrated that strains SMFC-7 and SMFC-17 possess a significant ability to produce electricity.

While numerous electricigens have been observed, the majority of research focused on a group of highly electroactive species, such as Geobacter and Shewanella. Geobacter, however, was a strict anaerobe with a relatively high level of electroactivity, but it was usually accompanied by slower growth rates, which could pose challenges in real-world applications. On the contrary, Shewanella was a facultative anaerobic microorganism with diverse metabolic modes (Ong et al., 2014), which was an example of a less picky electricigens. Doyle and Marsili (2018) have suggested that some strains may quickly be ruled out because they produce a low current. However, the weakly electroactive populations and communities may have certain application prospects in bioprocesses, biosensors, and bioremediation. Some researchers have classified microbes that produce low currents or low coulomb efficiencies as weak 

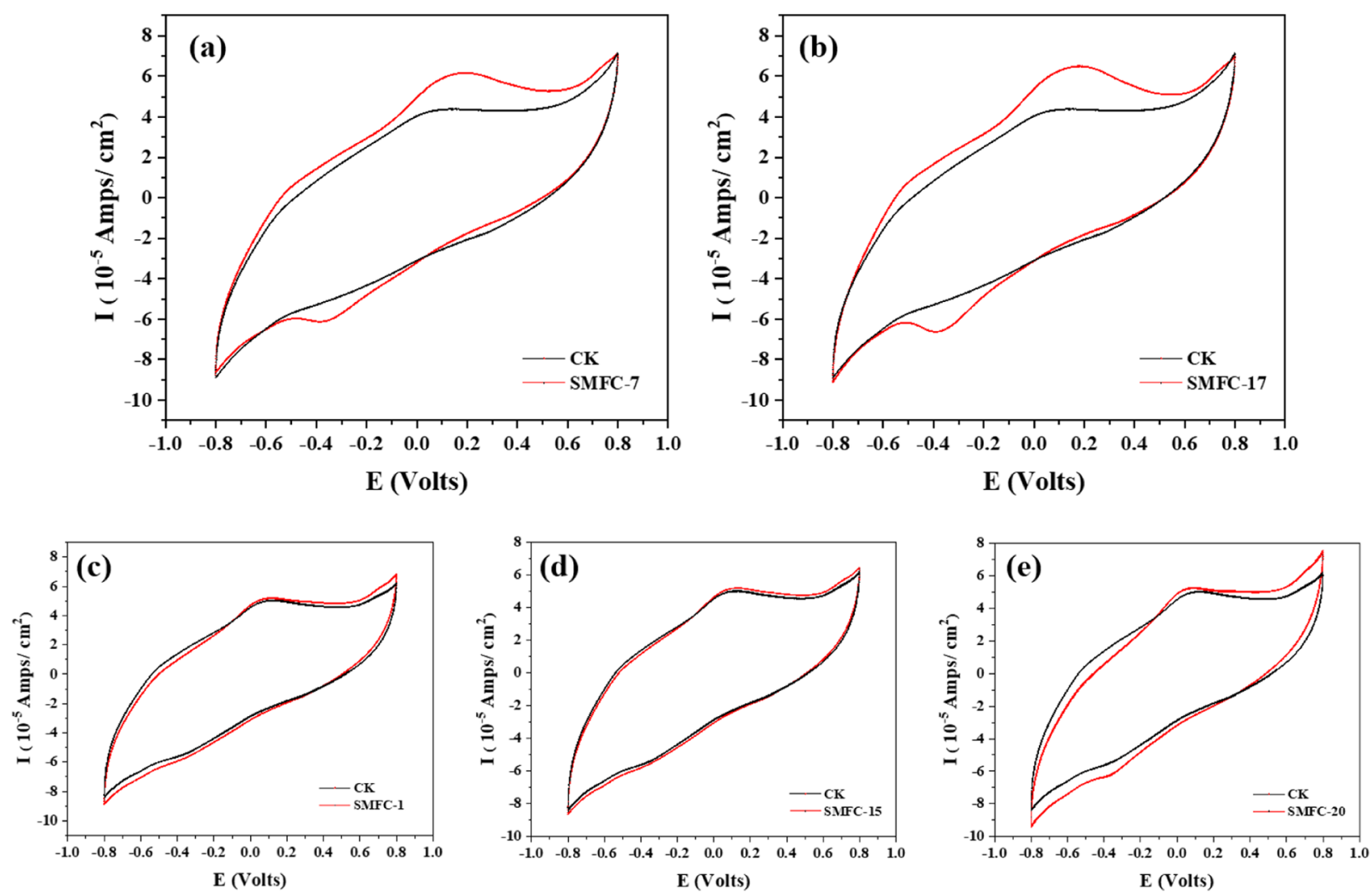

Fig. 1 Cyclic voltammetry curves of strains: a SMFC-7, b SMFC-17, c SMFC-1, d SMFC-15, e SMFC-20

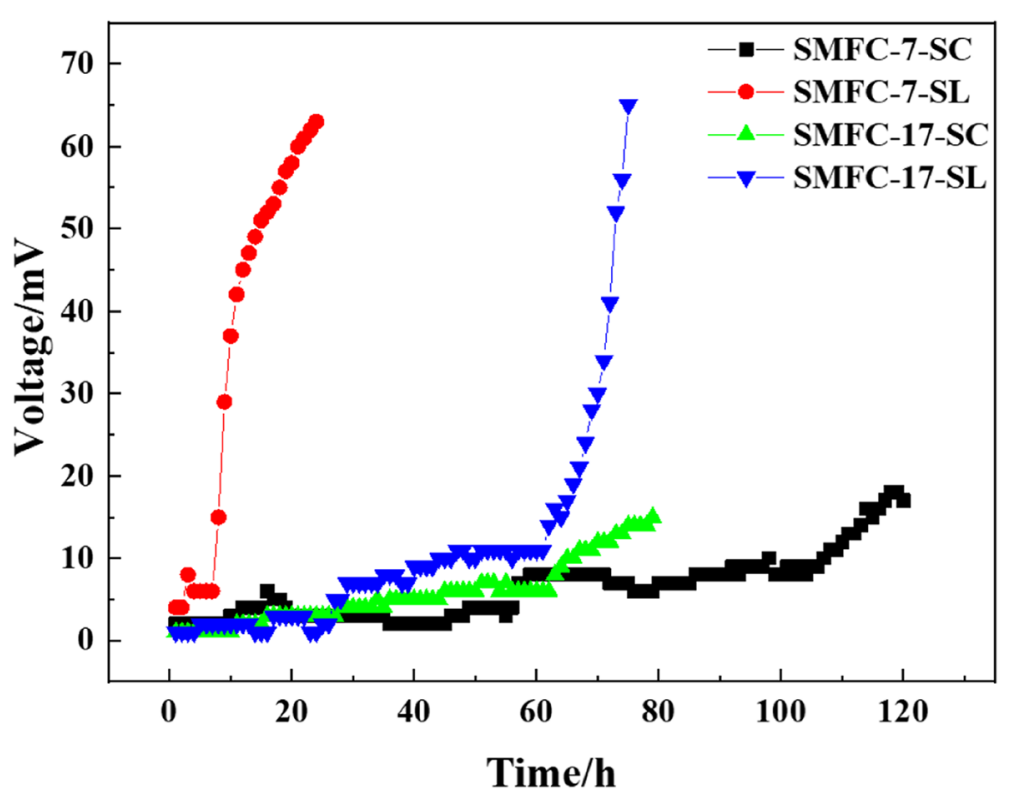

Fig. 2 The output voltage of strain under different carbon source 
electricigens (Doyle \& Marsili, 2018). Weak electricigens could be broadly distributed across nature (Chabert, Amin, \& Achouak, 2015; Cournet, Délia, Bergel, Roques, \& Bergé, 2010). Compared with strong electricigens, weak electricigens could compensate for metabolic shortcomings and realize more stable bioprocess in a mixed community (Doyle \& Marsili, 2018). Bacillus is a type of weak electricigen. Bacillus thuringiensis DRR-1 from cow rumen produced a small potential and current when cultivated in an MFC with an unspecified medium (Jothinathan \& Wilson, 2017). Nonetheless, Bacillus spp. may also play a synergistic role in co-culture bioelectrochemical devices. When co-cultured Bacillus subtilis RH33 with Shewanella oneidensis MR-1, Liu, Yu, Chen, and Chen (2017) found that the power output increased significantly and confirmed that MR-1 could efficiently utilize the high concentration of riboflavin produced by RH33 to improved MFC performance. Wu, Xiabo, et al. (2014) and You et al. (2018) also found that $B a$ cillus could secrete flavins which were able to act as electron shuttles, strengthening the electron transfer from microorganism to the electrode. According to the above studies, Bacillus had the ability to secrete riboflavin. Previous researches have been reported that some species of Geobacter, Shewanella, Bacillus, and other microorganisms could rely on flavin molecules for mediated electron transfer (MET) (Kumar et al., 2016; Li, Tiedje, Chiu, \& Worden, 2012; Wu et al., 2013; You et al., 2018). Therefore, as an electron shuttles, riboflavin played an important role in extracellular electron transfer.

\section{Identification of strains SMFC-7 and SMFC-17 Morphological character}

The colony morphology of SMFC-7 on nutrient agar under aerobic conditions was faint yellow, domed, and was approximately $3 \mathrm{~mm}$ in diameter. The edge condition was regular and the varnish was glossy. Compared with SMFC-7, the diameter of SMFC-17 is bigger, approximately $5 \mathrm{~mm}$ under the same culture time, and its color is milk white. They were facultative anaerobe, Gram-positive bacteria. A subset of the study reported that electricigens are facultative anaerobic bacteria, e.g., Shewanella putrefaciens (Rabaey, Boon, Siciliano, Verhaege, \& Verstraete, 2004), Pseudomonas aeruginosa (Nimje et al., 2009), Bacillus subtilis (Zhou et al., 2017), and Citrobacter freundii (Seo \& Roh, 2018). Since facultative strains possess many desirable properties compared to anaerobic strains, such as their ability to survive in anaerobic and aerobic conditions, these strains represent a promising exoelectrogenic species in engineering of biological catalysts for microbial electrochemistry.

\section{Phylogenetic analysis}

One thousand four hundred two base pairs and $1425 \mathrm{bp}$ target fragments were amplified by PCR using strain SMFC-7 and strain SMFC-17 genome DNA as template. The sequence similarity of the $16 \mathrm{~S}$ rDNA gene was compared with those of reference microorganisms obtained from GenBank data libraries. The result showed that the isolated strains SMFC-7 and SMFC-17 belonged to the genus Bacillus (Fig. 3). Bacillus cereus was the nearest neighbor of both strains, with a $16 \mathrm{~S}$ rDNA sequence similarity of 100\% (SMFC-7) and 99\% (SMFC-17). In the systematic classification and identification, when the homology of 16S rDNA gene sequence is greater than $97 \%$, it can be considered as one species (Embley \& Stackebrandt, 1994). According to its morphological, physiological, and biochemical characteristics, along with phylogenetic analysis, these two strains were identified as Bacillus cereus (Table 1). The highest proportion of Bacillus was found by testing the microbial community structure of the anode biofilm, reaching $22.5 \%$ of microbial community (Xu et al., 2017). Through our experiment, it can be proved that the type of electricigens present in the anode of SMFC belongs to Bacillus.

\section{Some performances of SMFC-7 and SMFC-17 Optimum growth conditions and growth curve}

It was found that two strains both can grow in the range of $20-45{ }^{\circ} \mathrm{C}$ and grows fastest between $30-37{ }^{\circ} \mathrm{C}$. From the growth curves of the two strains at different $\mathrm{pH}$, we know that the optimum $\mathrm{pH}$ condition of SMFC-7 is 6-8, and the optimum $\mathrm{pH}$ condition of SMFC-17 is 6-9 (Fig. 4). Compared with SMFC7, SMFC17 is more tolerant to acid and base conditions.

\section{Iron reduction rate}

Most of the electricigens have iron reducing properties (Liu et al., 2016; Liu \& Wang, 2016; Park et al., 2001). We enriched iron-reducing bacteria through SMFC anode biofilm and found that strains SMFC-7 and SMFC-17 had strong redox properties and could use organic carbon sources to produce electricity. Electrochemical experiment verified the feasibility of obtaining electricigens by screening iron-reducing bacteria. Test results of the iron reduction ability of two strains of electrogenic microorganisms were shown in Fig. 5, and we found that both strains SMFC-7 and SMFC-17 have significant iron reducibility. The maximum iron reduction rate under the condition of $20 \mathrm{mM}$ ferric citrate is $15.92 \pm 0.13 \%$ and $15.16 \pm 0.80 \%(p=0.450)$, respectively. It increased under $5 \mathrm{mM}$ ferric citrate conditions, reaching $29.59 \pm 1.99 \%$ and $21.43 \pm 1.67 \%(p=0.011)$, respectively.

Strains SMFC-7 and SMFC-17 had the largest accumulation of $\mathrm{Fe}$ (II) on the first day, which may be due to 
(a)

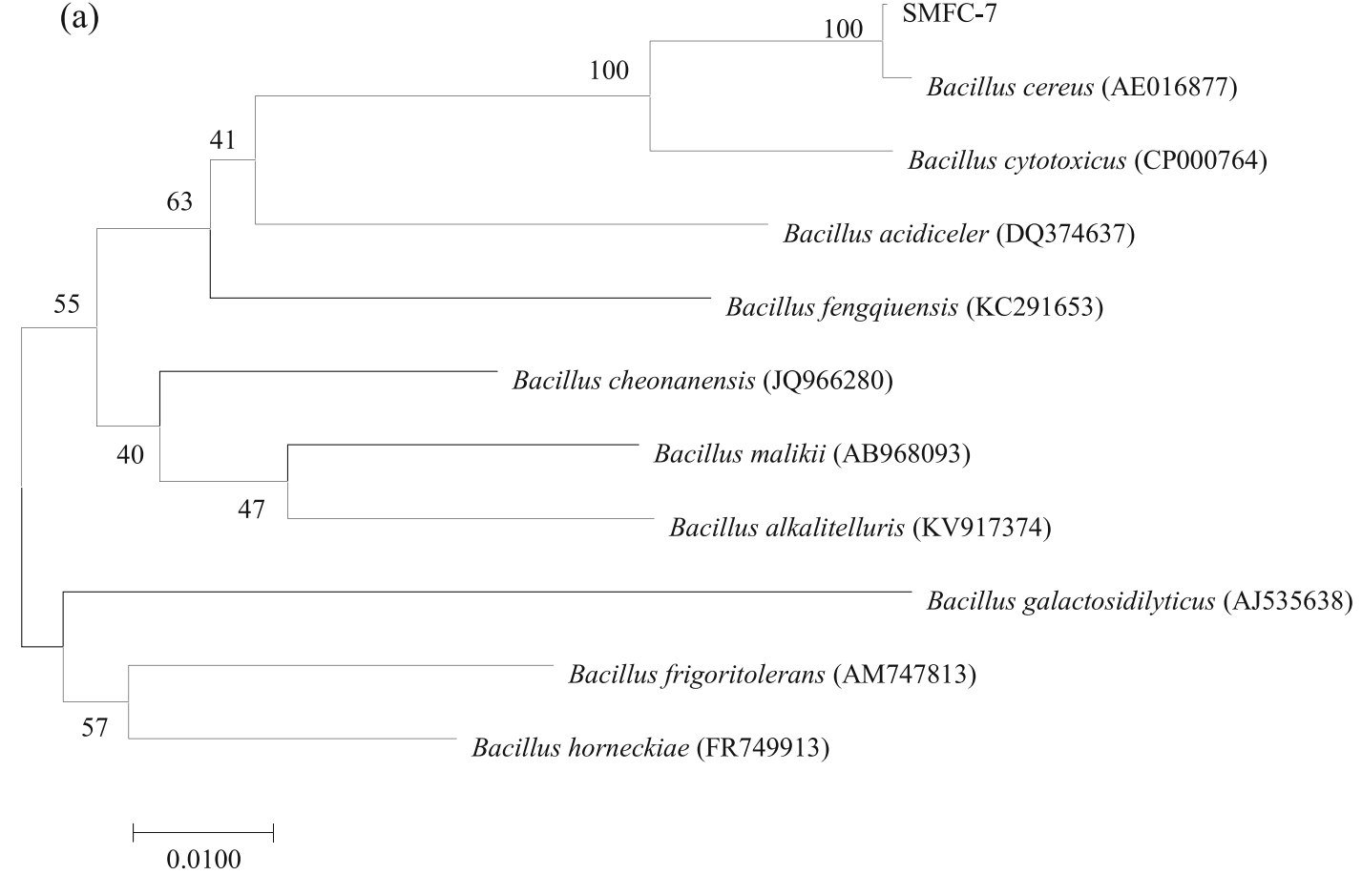

(b)

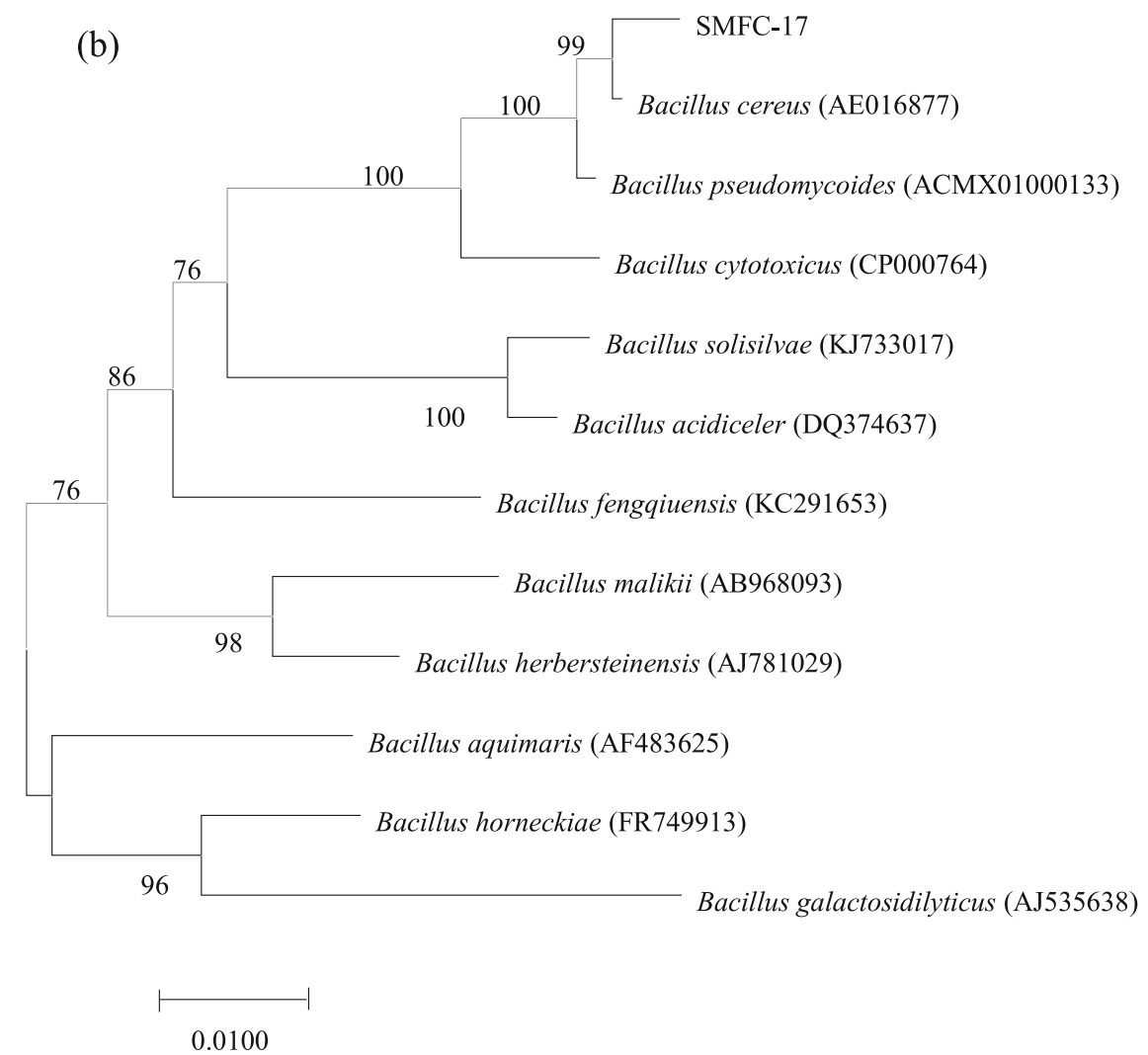

Fig. 3 Phylogenetic tree of strain SMFC-7, SMFC-17: a SMFC-7, b SMFC-17 
Table 1 Parts of physiological and biochemical properties of strains

\begin{tabular}{llll}
\hline Characteristics & SMFC-7 & SMFC-17 & Bacillus cereus \\
\hline Gram reaction & + & + & + \\
Dynamic test & + & + & \pm \\
Nitrate test & + & + & + \\
VP test & - & - & \pm \\
Catalase & + & + & + \\
Xylose-gelatin & - & - & \pm \\
Mannitol & - & - & - \\
Lysozyme tolerance & + & + & + \\
Protein toxin crystal & - & - & - \\
\hline
\end{tabular}

the stronger reduction of $\mathrm{Fe}(\mathrm{III})$ during the growth of strains SMFC-7 and SMFC-17 (García-Balboa et al., 2010; Liu \& Wang, 2016). At the ferric citrate concentration of $20 \mathrm{mM}$, we found the decrease on Fe(III) reduction compared to $5 \mathrm{mM}$ ferric citrate. Compared with the $5 \mathrm{mM}$ ferric citrate solution, the $20 \mathrm{mM}$ ferric citrate solution had more Fe(III), and these excess Fe(III) may negatively impact the enrichment of $\mathrm{Fe}(\mathrm{III})$-reducing bacteria (Liu \& Wang, 2016). The reason may be that the excess amount of $\mathrm{Fe}$ (III) caused $\mathrm{Fe}(\mathrm{III})$ reducing bacteria to form an iron mineral coatings on cell surface, which was detrimental to cell growth and microbial activity (Liu, Zachara, Gorby, Szecsody, \& Brown, 2001).

\section{Concentration variation of nitrogen and phosphorus}

As shown in Fig. $6 \mathrm{a}-\mathrm{C}$, the concentration of $\mathrm{NO}_{3}{ }^{-}-\mathrm{N}$ decreased sharply on the second day compared with the initial concentration $(p=0.000)$ and fluctuated within a small range in the following days in the system of inoculation of strain SMFC-7. The lowest concentration reached $3.72 \pm 0.26 \mathrm{mg} / \mathrm{L}$ and the removal rate was $83.48 \pm 1.16 \%$. The concentration of $\mathrm{NH}_{4}{ }^{+}-\mathrm{N}$ declined slowly compared with SMFC-17 and the mixed bacteria system, and the removal rate reaches $18.97 \pm 3.17 \%$ on the 7th day. The concentration of $\mathrm{NO}_{2}{ }^{-} \mathrm{N}$ rose sharply on the second day, reaching $37.6 \pm 0.04 \mathrm{mg} / \mathrm{L}$, and then basically stayed the same. The concentration changes of $\mathrm{NO}_{3}{ }^{-}-\mathrm{N}$ and $\mathrm{NO}_{2}{ }^{-}-\mathrm{N}$ in the system when inoculating strain SMFC-17 is similar to the one observed after the inoculation of SMFC-7. The lowest concentration of $\mathrm{NO}_{3}{ }^{-}-\mathrm{N}$ reached $4.22 \pm 0.25 \mathrm{mg} / \mathrm{L}$ and the removal rate was $81.26 \pm 1.11 \%$, while the concentration of $\mathrm{NH}_{4}{ }^{+}-\mathrm{N}$ dropped significantly on the third day and dropped to $29.10 \pm 9.19 \mathrm{mg} / \mathrm{L}$ on the 7 th day; the removal rate reaches about $79.91 \pm 6.34 \%$ on the 7 th day. For the pure bacteria system, the concentration of $\mathrm{NO}_{3}{ }^{-}-\mathrm{N}$ decreased while the concentration of $\mathrm{NO}_{2}^{-}-\mathrm{N}$ increased. We confirmed the capability of the high capability of $\mathrm{Ba}$ cillus strain to convert nitrate in nitrite, as already observed by Cho and Rhee (2019). The concentration of $\mathrm{NO}_{2}{ }^{-}-\mathrm{N}$ increased was higher than that of $\mathrm{NO}_{3}{ }^{-} \mathrm{N}$, which may be due to the conversion of ammonium to nitrite. Yang, Lin, and Huang (2017) isolated an aerobic denitrifying bacterium from a bio-trickling filter treating NOx, Bacillus sp. K5. It was found that hydroxylamine oxidase (HAO) played a key role. Higher nitrite accumulation was observed during ammonium oxidization by a pure strain of ammonia-oxidizing bacteria $(\mathrm{AOB})$ or a population of $\mathrm{AOB}$ in an activated sludge system (Fumasoli et al., 2017; Miao et al., 2017; Zou, Yao, \& Ni, 2014). We can suspect the possibility that isolated bacteria SMFC-7 and SMFC-17 also oxidize ammonia by HAO. In the system-inoculated SMFC-17, we found that the
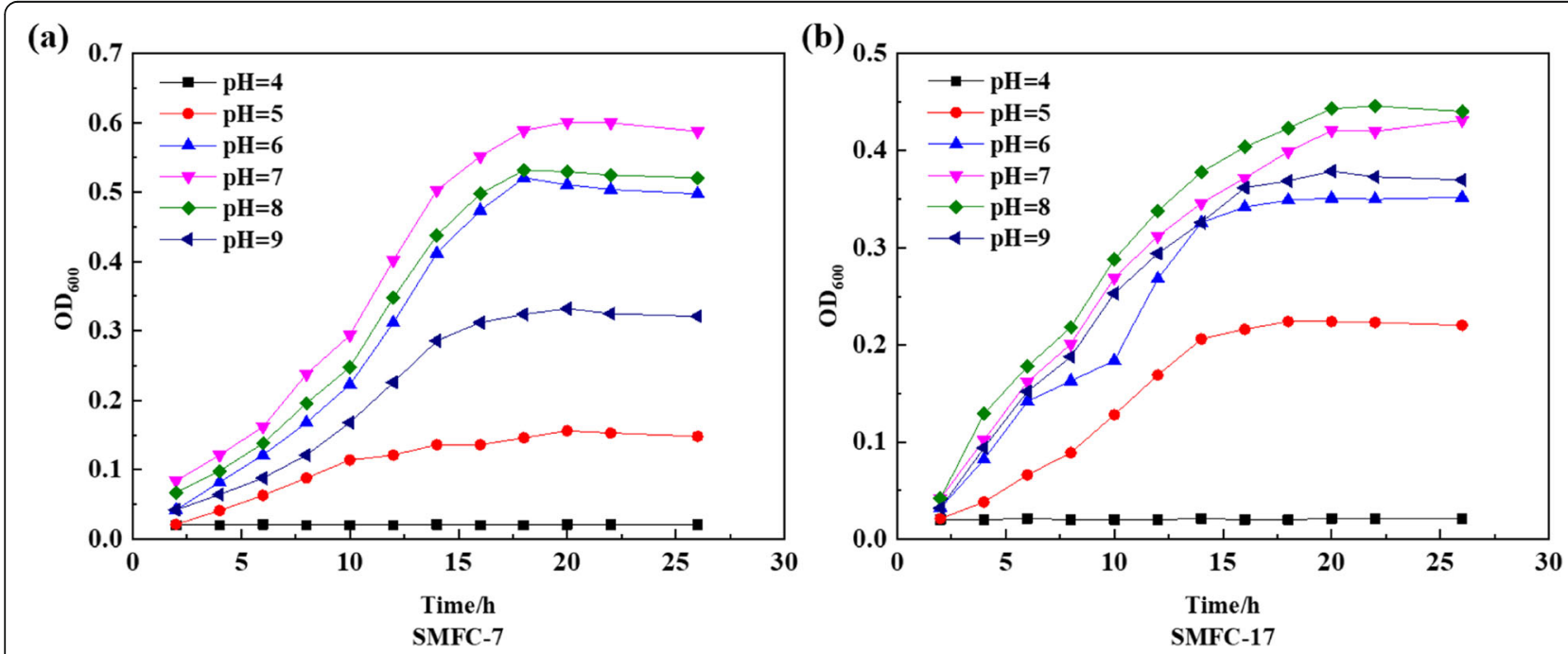

Fig. 4 Growth curve under different pH: a SMFC-7, b SMFC-17 

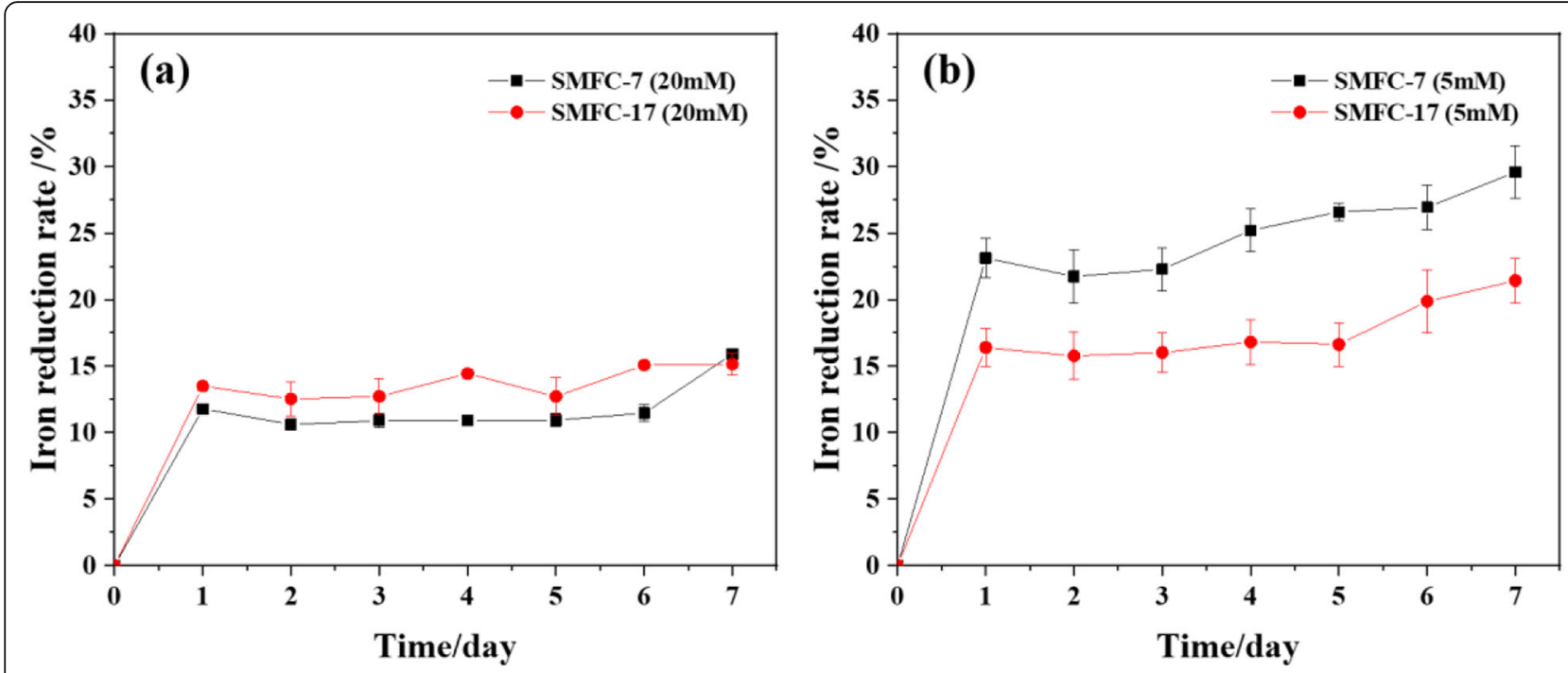

Fig. 5 Iron reduction rate of SMFC-7 and SMFC-17: a 20 mM ferric citrate, b 5 mM ferric citrate

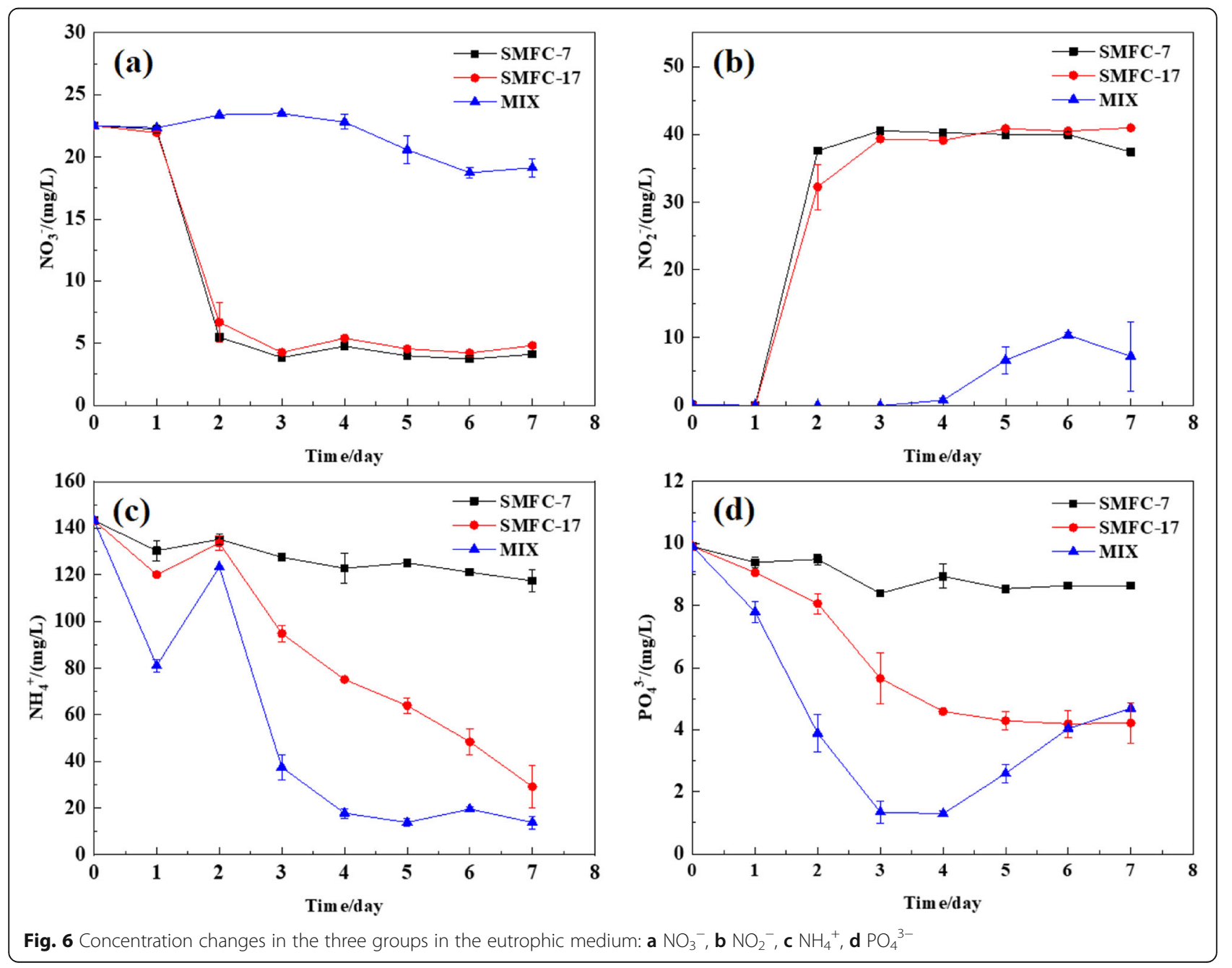


concentration of $\mathrm{NO}_{3}{ }^{-}-\mathrm{N}$ and $\mathrm{NH}_{4}{ }^{+}-\mathrm{N}$ decreased by $17.72 \mathrm{mg} / \mathrm{L}$ and $114.20 \mathrm{mg} / \mathrm{L}$, respectively, and $\mathrm{NO}_{2}{ }^{-}{ }^{-} \mathrm{N}$ increased by $40.94 \mathrm{mg} / \mathrm{L}$. After the second day, the concentration of $\mathrm{NO}_{3}{ }^{-}-\mathrm{N}$ and $\mathrm{NO}_{2}{ }^{-}-\mathrm{N}$ showed no significant change, while $\mathrm{NH}_{4}{ }^{+}-\mathrm{N}$ decreased significantly $(p=$ 0.000). All these results indicate that strain SMFC-17 preferred to remove ammonium in the mixed $\mathrm{N}$-source, which might be attributed to the higher enzyme activity of ammonium oxidization than that of nitrate reduction (Yang, Liu, \& Wang, 2019).

The variation trends of nitrogen and phosphorus concentration of mixed bacteria system and pure bacteria system were different. In the mixed bacteria system, the concentration of $\mathrm{NO}_{3}{ }^{-}-\mathrm{N}$ changes slowly, and the lowest concentration reaches $18.74 \pm 0.45 \mathrm{mg} / \mathrm{L}$ on the 6 th day. The $\mathrm{NH}_{4}{ }^{+}-\mathrm{N}$ concentration displayed obvious fluctuations, presenting a first decline and then slowly increasing during the first 3 days. It had a perfect performance in the removal of $\mathrm{NH}_{4}{ }^{+}-\mathrm{N}$, the highest removal rate reached to $90.49 \pm 1.86 \%$, and almost no nitrite nitrogen accumulation in the first 4 days. Nakano, Shimizu, Okumura, Sugahara, and Maeda (2008) constructed a consortium comprising $\mathrm{AOB}$, and denitrifying bacteria removed roughly $90 \%$ of $\mathrm{NH}_{4}{ }^{+}-\mathrm{N}$ in 37 days when they were incubated in an ANA3 medium containing equal concentrations of $\mathrm{NH}_{4}{ }^{+}-\mathrm{N}$ and $\mathrm{NO}_{3}{ }^{-}-\mathrm{N}\left(56 \mathrm{mg} \mathrm{L}{ }^{-1}\right)$. However, the $\mathrm{NO}_{2}{ }^{-} \mathrm{N}$ in the medium increased to 74.2 $\mathrm{mg} \mathrm{L}^{-1}$. Yang, Liu, and Wang (2019) isolated a consortium of $\mathrm{AOB}$ from landfill leachate through persistent domestication, and the consortium showed approximately $90.85 \pm 0.80 \%$ and $77.88 \pm 1.86 \%$ removal of $\mathrm{NH}_{4}{ }^{+}-\mathrm{N}$ in a bioaugmentation treatment of eutrophic wastewater with an initial concentration of $1.80 \pm 0.04$ $\mathrm{mg} \mathrm{L}^{-1}$ and $40.31 \pm 0.57 \mathrm{mg} \mathrm{L}^{-1}$, respectively. A high efficiency of ammoxidation and relatively low accumulation of nitrite were obtained by these mixed bacteria systems in the present study compared with those consortiums. In the 5th day, the concentration of $\mathrm{NH}_{4}{ }^{+}-\mathrm{N}$ was accumulated, it probably owing to the strains entered decline phase and the release of ammonium from the dead bacteria cell caused by insufficient organic compound (Yang, Wang, Chen, \& Lyu, 2019). The removal efficiency of $\mathrm{NO}_{3}{ }^{-}-\mathrm{N}$ in mixed bacteria is much lower than that in pure bacteria, indicating that denitrification exists to convert $\mathrm{NO}_{2}{ }^{-}-\mathrm{N}$ or $\mathrm{NH}_{4}{ }^{+}-\mathrm{N}$ into $\mathrm{NO}_{3}{ }^{-}$ $\mathrm{N}$. The maximum nitrogen removal efficiency of inoculation with SMFC-7, SMFC-17, and mixed bacteria reached about $8 \%, 55 \%$, and $76 \%$, respectively. The mechanism of nitrogen removal needs to be explained by further experiments.

The concentration of $\mathrm{PO}_{4}{ }^{3-}$ varied under three systems (as shown in Fig. 6d). The inoculation of strain SMFC-7 produced minimal variation in phosphate concentration and the lowest concentration was around 8.39 $\pm 0.00 \mathrm{mg} / \mathrm{L}$, while significant variations were observed after inoculating strain SMFC-17 and the mixed-species inoculum. When inoculating strain SMFC-17, phosphate content stabilized to $4.59 \pm 0.08 \mathrm{mg} / \mathrm{L}$. With the mixedspecies inoculum, the concentration dropped to the lowest amount of $1.29 \pm 0.10 \mathrm{mg} / \mathrm{L}$.

$\mathrm{PO}_{4}{ }^{3-}$-accumulating organisms (PAOs) can accumulate abundant $\mathrm{PO}_{4}{ }^{3-}$ under aerobic conditions and transfer poly- $\mathrm{PO}_{4}{ }^{3-}$ to ATP under anaerobic conditions to assist in the synthesis of polyhydroxyalkanoates (Han et al., 2018). The strain SMFC-7 had weak absorption capacity of $\mathrm{PO}_{4}{ }^{3-}$, the accumulation rate only reaches $15.25 \pm 0.00 \%$, and the change is small within 7 days; we can speculate that the strain is not a PAO. Strain SMFC17 has a strong absorption capacity for $\mathrm{PO}_{4}{ }^{3-}$, and its absorption efficiency is as high as $57.68 \pm 4.36 \%$; the loss might be due to adsorptive $\mathrm{PO}_{4}{ }^{3-}$ removal by extra polymeric substances (EPS) of the microbial cell (Rout, Bhunia, \& Dash, 2017). Due to the decrease of electron acceptors or DO, there were changes after the 4th day. Strain SMFC-17 was metabolically capable of utilizing nitrate or nitrite without any inhibitory effect on phosphate uptake, so it might be a denitrifying phosphateaccumulating organism (DPAO). Under the mixed bacteria condition, the phosphorus absorption capacity reached to $86.97 \pm 1.01 \%$ on the third day, followed by a small amount of release, which might be owing to the strains entering the decline phase and the release of $\mathrm{PO}_{4}{ }^{3-}$ from the dead bacteria cell caused by insufficient organic compound; the production of $\mathrm{NO}_{2}{ }^{-}-\mathrm{N}$ in the 4th day has a certain toxic effect on some strains or the system DO drops (Rout et al., 2017; Weon, Lee, Lee, \& Koopman, 2002; Zhou et al., 2010; Zhou, Pijuan, \& Yuan, 2007). During the system of inoculating strain SMFC-17 and mixed bacteria, the nitrogen removal performance and phosphorus accumulation efficiency proved that $\mathrm{P}$ removal could occur during with heterotrophic nitrification aerobic denitrification process.

The reason for the little change in pollutant content after dropping to a certain level may be that high microbial growth resulted in depletion of oxygen in the medium which might be responsible for inhibiting enzyme system, consequently repressing the nutrient removal activity. Taking cost-effectiveness into account, a simultaneous heterotrophic-nitrifying, aerobicdenitrifying, and polyphosphate-accumulating microorganism is highly essential for efficient treatment of nutrient-rich wastewater. Owing to the significant nutrient removal efficiency, it was suggested that strain SMFC-17 had a broad application prospect in terms of wastewater or sediment treatment emphasizing on simultaneous organic, nitrogen and phosphorous removal in the same reactor. Previous studies have showed that the microbial composition of the anode, especially the 
relative abundance of electricigens, had a significant effect on the performance of SMFC (Zhou et al. 2015; Ewing et al., 2017). As a solid electron acceptor, electricigens could grow and attach on the electrode surface (Doyle \& Marsili, 2015; Pandey et al., 2016). Since microbial immobilization has been considered to be an effective strategy to induce biofortification performance (Liu, Li, Shi, Zhu, \& Gao, 2013; Wang et al., 2013), fixing strain SMFC-17 to the anode of SMFC might also be an effective means to improve SMFC performance. Shi et al. (2019) co-cultivated the active carbon fibers with $S$. oneidensis MR-1 at $150 \mathrm{rpm}$ and $30{ }^{\circ} \mathrm{C}$ for 6 days to ensure the strain MR-1 got immobilized on the anode surface sufficiently. As a facultative anaerobe, SMFC-17 could not only be fixed in the anaerobic anode but also in the aerobic cathode, which is expected to improve the treatment effect of SMFC on sediments and overlying water pollutants. In order to improve the performance of strain SMFC-17 in the treatment of reagent contaminants, it can also be considered to be combined with other technologies. Seo and Roh (2018) used the combination of biologically synthesized Pd-FeS and Bacillus cereus to enhance the efficiency of aerobic nitrogen removal at a circumneutral condition.

\section{Conclusion}

In this study, two strains of iron-reducing electricigens were obtained by screening from the anode biofilm under micro-oxygen conditions. According to its morphological, physiological, and biochemical characteristics, along with phylogenetic analysis, these two strains were identified as Bacillus cereus. Compared with SFMC-7, the strain SMFC-17 exhibited outstanding ability to remove nitrogen and accumulate phosphorous simultaneously from eutrophic solution under experimental condition and the efficiency of $\mathrm{NH}_{4}{ }^{+}-\mathrm{N}, \mathrm{NO}_{3}{ }^{-}-\mathrm{N}$ removal, and $\mathrm{PO}_{4}{ }^{3-}-\mathrm{P}$ accumulation with the removal rate of $79.91 \pm 6.34 \%$ and $81.26 \pm 1.11 \%$ and accumulation rate of $57.68 \pm 4.36 \%$, respectively. Strain SMFC- 17 might be a useful biocatalyst to enable the industrialized application of SMFC in eutrophic water treatment.

\section{Additional files}

Additional file 1 Genne sequence.

Additional file $\mathbf{2}$ Original data.

\section{Publisher's note}

Springer Nature remains neutral with regard to jurisdictional claims in published maps and institutional affiliations.

\section{Acknowledgements}

We thank the other members of our group, who gave us advice and suggestions regarding this work, for their selfless contributions. This work was supported by the Strategic Priority Research Program of the Chinese Academy of Sciences, Grant No. XDA23040401.
Competing interests

The authors declare that they have no conflict of interest.

Ethics approval and consent to participate

N/A.

Consent for publication

N/A.

Authors' contributions

XZ performed the experiments and drafted the manuscript. XZ, HpZ, and QrC analyzed the data. CW and YqZ contributed reagents/materials/analysis tools. QhZ and ZbW conceived of the study and participated in its design and coordination. The authors read and approved the final manuscript.

\section{Funding}

The Strategic Priority Research Program of the Chinese Academy of Sciences, Grant No. XDA23040401.

\section{Author details}

'College of Resources and Environmental Engineering, Wuhan University of Technology, Wuhan 430070, People's Republic of China. ${ }^{2}$ State Key Laboratory of Freshwater Ecology and Biotechnology, Institute of Hydrobiology, Chinese Academy of Sciences, Wuhan 430072, People's Republic of China.

Received: 11 September 2019 Accepted: 23 April 2020

Published online: 30 April 2020

\section{References}

Beusen AHW, Bouwman AF, Van Beek LPH, Mogollón JM, Middelburg JJ (2016) Global riverine $\mathrm{N}$ and $\mathrm{P}$ transport to ocean increased during the 20th century despite increased retention along the aquatic continuum. Biogeosciences 13: 2441-2451 https://doi.org/10.5194/bg-13-2441-2016

Biffinger JC, Fitzgerald LA, Ray R, Little BJ, Lizewski SE, Petersen ER, Ringeisen BR, Sanders WC, Sheehan PE, Pietron JJ, Baldwin JW, Nadeau LJ, Johnson GR, Ribbens M, Finkel SE, Nealson KH (2011) The utility of Shewanella japonica for microbial fuel cells. Bioresource Technology 102:290-297. https://doi.org/10. 1016/j.biortech.2010.06.078

Chabert N, Amin AO, Achouak W (2015) All ecosystems potentially host electrogenic bacteria. Bioelectrochem 106:88-96 https://doi.org/10.1016/j. bioelechem.2015.07.004

Cho TJ, Rhee MS (2019) Underrecognized niche of spore-forming bacilli as a nitrite-producer isolated from the processing lines and end-products of powdered infant formula. Food Microbiology 80:50-61 https://doi.org/10. 1016/j.fm.2018.12.012

Cournet A, Délia M, Bergel A, Roques C, Bergé M (2010) Electrochemical reduction of oxygen catalyzed by a wide range of bacteria including Grampositive. Electrochemistry Communications 12:505-508 https://doi.org/10. 1016/j.elecom.2010.01.026

Doyle LE, Marsili E (2015) Methods for enrichment of novel electrochemicallyactive microorganisms. Bioresource Technology 195:273-282 https://doi.org/ 10.1016/j.biortech.2015.07.025

Doyle LE, Marsili E (2018) Weak electricigens: A new avenue for bioelectrochemical research. Bioresource Technology 258:354-364 https:// doi.org/10.1016/j.biortech.2018.02.073

Embley TM, Stackebrandt E (1994) The molecular phylogeny and systematics of the actinomycetes. Annual Review of Microbiology 48:257-289 https://doi. org/10.1146/annurev.micro.48.1.257

Ewing T, Ha PT, Beyenal H (2017) Evaluation of long-term performance of sediment microbial fuel cells and the role of natural resources. Applied Energy 192:490-497 https://doi.org/10.1016/j.apenergy.2016.08.177

Fumasoli A, Bürgmann H, Weissbrodt DG, Wells GF, Beck K, Mohn J, Morgenroth E, Udert KM (2017) Growth of Nitrosococcus-related ammonia oxidizing bacteria coincides with extremely low $\mathrm{pH}$ values in wastewater with high ammonia content. Environmental Science \& Technology 51:6857-6866 https://doi.org/10.1021/acs.est.7b00392

García-Balboa C, Bedoya IC, González F, Blázquez ML, Muñoz JA, Ballester A (2010) Bio-reduction of Fe(III) ores using three pure strains of Aeromonas hydrophila, Serratia fonticola and Clostridium celerecrescens and a natural 
consortium. Bioresource Technology 101:7864-7871 https://doi.org/10.1016/j. biortech.2010.05.015

Han YH, Fu T, Wang SS, Yu HT, Xiang P, Zhang WX, Chen DL, Li M (2018) Efficient phosphate accumulation in the newly isolated Acinetobacter junii strain LH4 3 Biotech 8:313-325 https://doi.org/10.1007/s13205-018-1338-4

Hong SW, Kim HS, Chung TH (2010) Alteration of sediment organic matter in sediment microbial fuel cells. Environmental Pollution 158:185-191 https:// doi.org/10.1016/j.envpol.2009.07.022

Islam MA, Ethiraj B, Cheng CK, Yousuf A, Khan MMR (2017) Electrogenic and antimethanogenic properties of Bacillus cereus for enhanced power generation in anaerobic sludge-driven microbial fuel cells. Energy and Fuels 31:6132-6139 https://doi.org/10.1021/acs.energyfuels.7b00434

Jothinathan D, Wilson RT (2017) Comparative analysis of power production of pure, coculture, and mixed culture in a microbial fuel cell. Energy Sources, Part A: Recovery, Utilization, and Environmental Effects 39:520-527 https:// doi.org/10.1080/15567036.2016.1233306

Kabutey FT, Ding J, Zhao QL, Antwi P, Quashie FK, Tankapa V, Zhang WX (2019) Pollutant removal and bioelectricity generation from urban river sediment using a macrophyte cathode sediment microbial fuel cell (mSMFC). Bioelectrochemistry 128:241-251 https://doi.org/10.1016/j.bioelechem.2019. 01.007

Karra U, Muto E, Umaz R, Kölln M, Santoro C, Wang L, Li B (2014) Performance evaluation of activated carbon-based electrodes with novel power management system for long-term benthic microbial fuel cells. International Journal of Hydrogen Energy 39:21847-21856 https://doi.org/10.1016/j. ijhydene.2014.06.095

Kim HJ, Park HS, Hyun MS, Chang IS, Kim M, Kim BH (2002) A mediator-less microbial fuel cell using a metal reducing bacterium, Shewanella putrefaciens. Enzyme and Microbial Technology 30:145-152 https://doi.org/10.1016/S01410229(01)00478-1

Kumar R, Singh L, Zularisam AW (2016) Exoelectrogens: Recent advances in molecular drivers involved in extracellular electron transfer and strategies used to improve it for microbial fuel cell applications. Renewable and Sustainable Energy Reviews 56:1322-1336 https://doi.org/10.1016/j.rser.2015. 12.029

Li R, Tiedje JM, Chiu C, Worden RM (2012) Soluble electron shuttles can mediate energy taxis toward insoluble electron acceptors. Environmental Science \& Technology 46:2813-2820 https://doi.org/10.1021/es204302w

Li WW, Yu HQ (2015) Stimulating sediment bioremediation with benthic microbial fuel cells. Biotechnology Advances 33:1-12 https://doi.org/10.1016/ j.biotechadv.2014.12.011

Liu C, Zachara JM, Gorby YA, Szecsody JE, Brown CF (2001) Microbial reduction of $\mathrm{Fe}(\mathrm{III})$ and sorption/precipitation of Fe(II) on Shewanella putrefaciens strain CN32. Environmental Science \& Technology 35:1385-1393 https://dio.org/1 $0.1021 /$ es0015139

Liu HY, Wang HY (2016) Characterization of Fe (III)-reducing enrichment culture and isolation of Fe (III)-reducing bacterium Enterobacter sp. L6 from marine sediment. Journal of Bioscience and Bioengineering 122:92-96 https://doi. org/10.1016/j.jbiosc.2015.12.014

Liu LH, Lee DJ, Wang AJ, Ren NQ, Su A, Lai JY (2016) Isolation of Fe(III)-reducing bacterium, Citrobacter sp. LAR-1, for startup of microbial fuel cell. International Journal of Hydrogen Energy 41:4498-4503 https://doi.org/10. 1016/j.ijhydene.2015.07.072

Liu N, Li HJ, Shi YE, Zhu BL, Gao S (2013) Biodegradation of high concentration of nitrobenzene by Pseudomonas corrugata embedded in peat-phosphate esterified polyvinyl alcohol. World Journal of Microbiology and Biotechnology 29:1859-1867 https://doi.org/10.1007/s11274-013-1348-7

Liu T, Yu YY, Chen T, Chen WN (2017) A synthetic microbial consortium of Shewanella and Bacillus for enhanced generation of bioelectricity. Biotechnology and Bioengineering 114:526-532 https://doi.org/10.1002/bit.26094

Lovley DR (2006) Microbial fuel cells: novel microbial physiologies and engineering approaches. Current Opinion in Biotechnology 17:327-332

Martins G, Peixoto L, Teodorescu S, Parpot P, Nogueira R, Brito AG (2014) Impact of an external electron acceptor on phosphorus mobility between water and sediments. Bioresource Technology 151:419-423 https://doi.org/10.1016/j. biortech.2013.10.048

Miao YY, Zhang L, Li BK, Zhang Q, Wang SM, Peng YZ (2017) Enhancing ammonium oxidizing bacteria activity was key to single-stage partial nitrification-anammox system treating low-strength sewage under intermittent aeration condition. Bioresource Technology 231:36-44 https:// doi.org/10.1016/j.biortech.2017.01.045
Morgane LM, Chantal GO, Ménesguen A, Souchon Y, Étrillard C, Levain A, Moatar F, Pannard A, Souchu P, Lefebvre A, Pinay G (2019) Eutrophication: a new wine in an old bottle? Sci Total Environ 651:1-11 https://doi.org/10.1016/j. scitotenv.2018.09.139

Nakano M, Shimizu Y, Okumura H, Sugahara I, Maeda H (2008) Construction of a consortium comprising ammonia-oxidizing bacteria and denitrifying bacteria isolated from marine sedimen. Biocontrol Science 13:73-89 https://doi.org/ 10.4265/bio.13.73

Nimje VR, Chen CY, Chen CC, Jean JS, Reddy AS, Fan CW, Pan KY, Liu HT, Chen JL (2009) Stable and high energy generation by a strain of Bacillus subtilis in a microbial fuel cell. Journal of Power Sources 190:258-263 https://doi.org/10. 4265/bio.13.73

Ong WK, Vu TT, Lovendahl KN, Llull JM, Serres MH, Romine MF, Reed J (2014) Comparisons of Shewanella strains based on genome annotations, modeling, and experiments. BMC Systems Biology 8:31 https://doi.org/10.1186/1752-0509-8-31

Pandey P, Shinde VN, Deopurkar RL, Kale SP, Patil SA, Pant D (2016) Recent advances in the use of different substrates in microbial fuel cells toward wastewater treatment and simultaneous energy recovery. Applied Energy 168:706-723 https://doi.org/10.1016/j.apenergy.2016.01.056

Park HS, Kim BH, Kim HS, Kim HJ, Kim GT, Kim M, Chang IS, Park YK, Chang HI (2001) A novel electrochemically active and Fe(III)-reducing bacterium phylogenetically related to Clostridium butyricum isolated from a microbial fuel cell. Anaerobe 7:297-306 https://doi.org/10.1006/anae.2001.0399

Pham CA, Jung SJ, Phung NT, Lee JY, Chang IS, Kim BH, Yi HN, Chun J (2003) A novel electrochemically active and Fe(III)-reducing bacterium phylogenetically related to Aeromonas hydrophila, isolated from a microbial fuel cell. FEMS Microbiology Letters 223:129-134. https://doi.org/10.1016/ S0378-1097(03)00354-9

Rabaey K, Boon N, Siciliano SD, Verhaege M, Verstraete W (2004) Biofuel cells select for microbial consortia that self-mediate electron transfer. Applied and Environmental Microbiology 70:5373-5382 https://doi.org/10.1128/aem.70.9. 5373-5382.2004

Rout PR, Bhunia P, Dash RR (2017) Simultaneous removal of nitrogen and phosphorous from domestic wastewater using Bacillus cereus GS-5 strain exhibiting heterotrophic nitrification, aerobic denitrification and denitrifying phosphorous removal. Bioresource Technology 244:484-495 https://doi.org/ 10.1016/j.biortech.2017.07.186

Sajana TK, Ghangrekar MM, Mitra A (2013) Application of sediment microbial fuel cell for in situ reclamation of aquaculture pond water quality. Aquacultural Engineering 57:101-107 https://doi.org/10.1128/aem.70.9.5373-5382.2004

Sajana TK, Ghangrekar MM, Mitra A (2014) Effect of operating parameters on the performance of sediment microbial fuel cell treating aquaculture water. Aquacultural Engineering 61:17-26 https://doi.org/10.1016/j.aquaeng.2014.05.004

Seo H, Roh Y (2018) Bio-minerals combined with Bacillus cereus for enhancing the nitrogen removal efficiency under aerobic conditions. Minerals 8:253-266 https://doi.org/10.3390/min8060253

Shi J, Zhao S, Yu X, Zhou T, Khan A, Yu Z, Feng P, Wang J, Liu P, Li X (2019) Enhanced performance of sediment microbial fuel cell by immobilization of Shewanella oneidensis MR-1 on an anode surface. International Journal of Hydrogen Energy 44:10091-10101 https://doi.org/10.1016/j.jihydene.2018.11.225

State EPA of China (2002) Monitoring and determination methods for water and wastewater, 4th edn. China Environmental Science Press, Beijing

Tao QQ, Luo JJ, Zhou J, Zhou SQ, Liu GL, Zhang RD (2014) Effect of dissolved oxygen on nitrogen and phosphorus removal and electricity production in microbial fuel cell. Bioresource Technology 164:402-407 https://doi.org/10. 1016/j.biortech.2014.05.002

Ueoka N, Kouzuma A, Watanabe K (2018) Electrode plate-culture methods for colony isolation of exoelectrogens from anode microbiomes. Bioelectrochemistry 124:1-6 https://doi.org/10.1016/j.bioelechem.2018.06.008

Virdis B, Rabaey K, Rozendal RA, Yuan ZG, Keller J (2010) Simultaneous nitrification, denitrification and carbon removal in microbial fuel cells. Water Research 44: 0-2980. doi:https://doi.org/10.1016/j.watres.2010.02.022

Wang C, He R, Wu Y, Lürling M, Cai H, Jiang HL, Liu X (2017) Bioavailable phosphorus $(P)$ reduction is less than mobile $P$ immobilization in lake sediment for eutrophication control by inactivating agents. Water Research 109:196-206 https://doi.org/10.1016/j.watres.2016.11.045

Wang JH, He HZ, Wang MZ, Wang S, Zhang J, Wei W, Xu HX, Lv ZM, Shen DS (2013) Bioaugmentation of activated sludge with Acinetobacter sp. TW enhances nicotine degradation in a synthetic tobacco wastewater treatment system. Bioresource Technology 142:445-453 https://doi.org/10.1016/j. biortech.2013.05.067 
Wang Y, Wang WH, Yan FL, Ding Z, Feng LL, Zhao JC (2019) Effects and mechanisms of calcium peroxide on purification of severely eutrophic water. Sc Total Environ 650:2796-2806 https://doi.org/10.1016/j.scitotenv.2018.10.040

Weon SY, Lee CW, Lee Sl, Koopman B (2002) Nitrite inhibition of aerobic growth of Acinetobacter sp. Water Research 36:0-4476. https://doi.org/10.1016/s00431354(02)00185-9

Wu C, Cheng YY, Li BB, Li WW, Li DB, Yu HQ (2013) Electron acceptor dependence of electron shuttle secretion and extracellular electron transfer by Shewanella oneidensis MR-1. Bioresource Technology 136:711-714 https:// doi.org/10.1016/j.biortech.2013.02.072

Wu S, Xiabo Y, Wang L, Zheng Y, Chang K, Zheng ZY, Yang ZH, Varcoe JR, Zhao F (2014) Extracellular electron transfer mediated by flavins in gram-positive Bacillus sp. WS-XY1 and Yeast Pichia stipitis. Electrochimica Acta 146:564-567 https://doi.org/10.1016/j.electacta.2014.09.096

Wu S, Xiao Y, Zheng ZW, Zheng Y, Yang ZH, Zhao F (2014) Isolation and identification of electrochemically active microorganism from micro-aerobic environment. Environmental Sciences 35:3933-3939 (in Chinese) https://doi. org/10.13227/j.hjkx.2014.10.041

Xiao Y, Zheng Y, Wu S, Yang ZH, Zhao F (2015) Bacterial community structure of autotrophic denitrification biocathode by 454 pyrosequencing of the $16 \mathrm{~S}$ rRNA gene. Microbial Ecology 69:492-499. https://doi.org/10.1007/s00248-014-0492-4

Xu M, Guo J, Cen Y, Zhang X, Cao W, Sun G (2005) Shewanella decolorationis sp. nov. a dye-decolorizing bacterium isolated from activated sludge of a wastewater treatment plant. International Journal of Systematic and Evolutionary Microbiology 55:363-368. https://doi.org/10.1099/ijs.0.63157-0

Xu P, Xiao ER, Xu D, Zhou Y, He F, Liu BY, Zeng L, Wu ZB (2017) Internal nitrogen removal from sediments by the hybrid system of microbial fuel cells and submerged aquatic plants. PLoS One 12:e0172757 https://doi.org/10.1371/ journal.pone.0172757

Yang JR, Wang Y, Chen H, Lyu YK (2019) Ammonium removal characteristics of an acid-resistant bacterium Acinetobacter sp. JR1 from pharmaceutical wastewater capable of heterotrophic nitrification-aerobic denitrification. Bioresource Technology 274:56-64 https://doi.org/10.1016/j.biortech.2018.10.052

Yang XL, Liu LH, Wang SB (2019) A strategy of high-efficient nitrogen removal by an ammonia-oxidizing bacterium consortium. Bioresource Technology 275: 216-224 https://doi.org/10.1016/j.biortech.2018.12.057

Yang YL, Lin ES, Huang SB (2017) Heterotrophic nitrogen removal in Bacillus sp. K5: involvement of a novel hydroxylamine oxidase. Water Science and Technology 76:3461-3467 https://doi.org/10.2166/wst.2017.510

Yang ZZ, Cheng YY, Zhang F, Li BB, Mu Y, Li WW, Yu HQ (2016) Rapid detection and enumeration of exoelectrogenic bacteria in lake sediments and a wastewater treatment plant using a coupled $\mathrm{WO}_{3}$ nanoclusters and most probable number method. Environmental Science \& Technology Letters 3: 133-137 https://doi.org/10.1021/acs.estlett.6b00112

You LX, Liu LD, Xiao Y, Dai YF, Chen BL, Jiang YX, Zhao F (2018) Flavins mediate extracellular electron transfer in Gram-positive Bacillus megaterium strain LLD-1. Bioelectrochemistry 119:196-202 https://doi.org/10.1016/j.bioelechem.2017.10.005

Zhou L, Deng DD, Zhang YC, Zhou W, Jiang YJ, Liu Y (2017) Isolation of a facultative anaerobic exoelectrogenic strain LZ-1 and probing electron transfer mechanism in situ by linking UVN Nis spectroscopy and electrochemistry. Biosensors \& Bioelectronics 90:264-268 https://doi.org/10. 1016/j.bios.2016.11.059

Zhou Y, Ganda L, Lim M, Yuan Z, Kjelleberg S, Ng WJ (2010) Free nitrous acid (FNA) inhibition on denitrifying poly-phosphate accumulating organisms (DPAOs). Applied Microbiology and Biotechnology 88:359-369 https://doi. org/10.1007/s00253-010-2780-3

Zhou Y, Pijuan M, Yuan Z (2007) Free nitrous acid inhibition on anoxic phosphorus uptake and denitrification by poly-phosphate accumulating organisms. Biotechnology and Bioengineering 98:903-912 https://doi.org/10.1002/bit.21458

Zhou YL, Jiang HL, Cai HY (2015) To prevent the occurrence of black water agglomerate through delaying decomposition of cyanobacterial bloom biomass by sediment microbial fuel cell. J Hazard Mater 287:7-15 https://doi. org/10.1016/j.jhazmat.2015.01.036

Zou S, Yao S, Ni JR (2014) High-efficient nitrogen removal by coupling enriched autotrophic-nitrification and aerobic-denitrification consortiums at cold temperature. Bioresource Technology 161:288-296 https://doi.org/10.1016/j. biortech.2014.03.066

Zuo Y, Xing DF, Regan JM, Logan BE (2008) Isolation of the exoelectrogenic bacterium Ochrobactrum anthropi YZ-1 by using a U-tube microbial fuel cell. Applied and Environmental Microbiology 74:3130-3137 https://doi.org/10. 1128/AEM.02732-07

Ready to submit your research? Choose BMC and benefit from:

- fast, convenient online submission

- thorough peer review by experienced researchers in your field

- rapid publication on acceptance

- support for research data, including large and complex data types

- gold Open Access which fosters wider collaboration and increased citations

- maximum visibility for your research: over $100 \mathrm{M}$ website views per year

At BMC, research is always in progress.

Learn more biomedcentral.com/submissions 